\title{
First functional morphology comparison between two Miocene cricetid mandibles
}

\author{
Patricia María CARRO-RODRÍGUEZ ${ }^{1,2, *}$, Paloma LÓPEZ-GUERREROI, Jérôme PRIETO, \\ Maria Ángeles ÁLVAREZ-SIERRA ${ }^{1,2}$ \& Pablo PELÁEZ-CAMPOMANES ${ }^{4}$
}

${ }^{1}$ Department of Geodynamics, Stratigraphy and Palaeontology (GEODESPAL), Universidad Complutense de Madrid, Madrid, Spain.patcarro@ucm.es*,palomalopez@geo.ucm.es

${ }^{2}$ Sedimentary Geology and Environmental Change, Geosciences Institute (CSIC, UCM), Madrid, Spain. masierra@ucm.es

${ }^{3}$ Department of Earth and Environmental Science, Palaeontology \& Geobiology, Ludwig-Maximilians-University Munich, Richard-Wagner-Str. 10, 80333 Munich, Germany. j.prieto@web.de

${ }^{4}$ Department of Paleobiology, Museo Nacional de Ciencias Naturales, CSIC. C/ José Gutiérrez Abascal 2, 28006 Madrid. pablopelaez@mncn.csic.es

${ }^{*}$ Corresponding author

Carro-Rodríguez, P.M., López-Guerrero, P., Prieto, J., Álvarez-Sierra, M.Á. \& Peláez-Campomanes, P. 2020. First functional morphology comparison between two Miocene cricetid mandibles. [Primera comparación de morfología funcional entre dos mandíbulas de cricétidos del Mioceno]. Spanish Journal of Palaeontology, 35 (2), 167-176.

Manuscript received 27 November 2019

Manuscript accepted 18 May 2020 https://doi.org/10.7203/sjp.35.2.18480

(C) Sociedad Española de Paleontología ISSN 2255-0550

\begin{abstract}
Geometric morphometric allows characterizing complex morphologies in order to quantify the geometry of the structure and facilitate comparisons. It allows performing methods analysing differentiation pattern based on variance, such as the Principal Component Analysis (PCA). For that reason, it has been chosen as the method to analyse the mandibles of two extinct species of cricetids rodents: Cricetodon aff. aureus and Megacricetodon minor from the MN6, middle Miocene from Goldberg and Steinberg (Germany). We performed a digitisation of 18 landmarks that includes the most relevant characteristics of these mandibles. We also performed a measure of the mechanical advantage and potential of the mandibles. In that way, we have been able to quantify notorious morphological differences on the angular and condylar processes and the lower masseter
\end{abstract}

RESUMEN

La morfometría geométrica permite caracterizar formas completas para cuantificar la geometría de la estructura y facilitar las comparaciones. Permite llevar a cabo metodologías que analizan esos patrones de diferenciación como el Análisis de Componentes Principales (ACP), a través del cual se estudia la varianza de una manera simple. Por esta razón ha sido el método elegido para analizar las mandíbulas de dos especies extintas de cricétidos: Cricetodon aff. aureus y Megacricetodon minor de la MN6, Mioceno medio de los yacimientos de Goldberg y Steinberg (Alemania). Hemos llevado a cabo la digitalización de 18 puntos de referencia (landmarks) que resumen las características más relevantes de las mandíbulas. Además hemos realizado la medición de las ventajas y potencias mecánicas de estas. De esta manera, hemos podido cuantificar diferencias morfológicas 
insertion and establish significant differences among the biomechanical behaviour of the mandibles. Later, we can relate the morphological and biomechanical information with speed and force biting.

Keywords: Cricetodon, Megacricetodon, geometric morphometric, middle Miocene, Germany notorias en los procesos angular y condilar y en la inserción del masetero inferior y establecer diferencias significativas entre los comportamientos biomecánicos de las mandíbulas para después relacionarlo con la velocidad y la fuerza de la mordida de estos roedores.

Palabras clave: Cricetodon, Megacricetodon, morfometría geométrica, Mioceno medio, Alemania.

\section{INTRODUCTION}

Shape and shape changes have been studied to understand the way in which the organisms or their parts vary as a consequence to different biological processes (Richtsmeier et al., 2002; Zelditch et al., 2004). These shape changes could be the result of ontogenetic development, adaptation to environmental factors or evolutionary diversification (Zelditch et al., 2004). In palaeontology, the study of shape is an essential requirement to carry out other analysis. For that reason, in recent years, geometric morphometric has revealed as a great tool to analyse and understand the morphological variation of fossils (Casanovas-Vilar \& van Dam, 2013; Siver et al., 2013; Gómez Cano et al., 2017; Tokita et al., 2017; Carro-Rodríguez et al., 2018). Geometric morphometric is a multivariate method to quantify the morphology of an object. It is based on an analysis of selected points (landmarks and semilandmarks) (Rohlf \& Marcus, 1993; Zelditch et al., 2004) that correspond to Cartesian coordinates. In geometric morphometric, most analysis measurements imply biological homology and thus considering them as the same point in each specimen in the study (Bookstein, 1996; Hall, 2003; Klingenberg, 2008; Oxnard \& O’Higgins, 2009) but not the position, scale and rotation of the object (Kendall, 1977; Baltanás et al., 2003; Zelditch et al., 2004; Toro Ibacache et al., 2010; Klingenberg, 2016).

Mammal mandible is one of the anatomical parts most used in these analyses because of its characteristic modularity, integration and biomechanics (Atchley, 1983, 1993; Andresen et al., 2000; Bastir et al., 2004; Zelditch et al., 2008; Menegaz \& Ravosa, 2017). The present morphological analysis has focused on the well-preserved mandibles of two extinct species of cricetids rodents (Rodentia) belonging to the genera: Cricetodon Lartet, 1851 and Megacricetodon Fahlbusch, 1964. Both are commonly used in biostratigraphic and paleoecological studies in European continental deposits during the middle Miocene (Mein, 1975; Aguilar, 1995; De Bruijn \& Ünay, 1996; Daams et al., 1999; Oliver Pérez et al., 2008; Prieto et al., 2010; Van der Meulen et al., 2011, 2012; LópezGuerrero et al., 2013, 2014; Van Dam et al., 2014, Prieto \& Rummel, 2016).
Studied mandibles were excavated in two close localities: Goldberg and Steinberg (formerly called Spitzberg) in the Nördlinger Ries of Southwest Germany. The Nördlinger Ries is a circular shallow depression formed due to a meteorite impact at $\sim 15 \mathrm{Ma}$ (Heizman \& Fahlbusch, 1983). This crater was like an isolated lake where spring mounds of calcareous tufa rose (Arp, 2006; Göhlich \& Ballmann, 2013). On the basis of small mammal remains, the faunas of Goldberg and Steinberg have been dated as upper Aragonian (MN6, middle Miocene) (Heizmann \& Fahlbusch, 1983). More precisely, they correlate to a time ranging from $\sim 15$ to $\sim 14.2 \mathrm{Ma}$ (Prieto \& Rummel, 2016; and reference therein) based on the evolutionary level of Cricetodon (Rummel, 2000). The abundant fossil remains of these localities display an exceptional preservation (Rachl, 1983; Ziegler, 1983; Heizmann \& Fahlbusch, 1983; Göhlich \& Ballmann, 2013), such as cranial structures, which are very uncommon in the fossil record. Heizmann \& Fahlbusch (1983) published the faunistic list of Steinberg and pointed out the similarities with the Goldberg fauna. The material studied in this work was assigned to Cricetodon sansaniensis and Megacricetodon schaubi by Heizmann \& Fahlbusch (1983). Later, Rummel (2000) assigned $C$. sansaniensis from Steinberg to $C$. aff. aureus and Freudenthal \& Fahlbusch (1969) pointed out that M. minor is the senior synonymous of M. schaubi. In that way, the nomenclatural state of the art is respectively $C$. aff. aureus and M. minor.

Although the best diagnostic characteristics of Cricetodon and Megacricetodon are based on dental morphological traits, Mein \& Freudental (1971a, 1971b) pointed out that there are some mandibular features that let establishing differences among these genera. These differences could be the result of generic level variation and/or a response to differential feeding behaviours (Atchley, 1993; Cox et al., 2012; Renaud et al., 2012; Anderson et al., 2014; Kono et al., 2017; Menegaz \& Ravosa, 2017). In order to establish the morphologic regions that gather the greatest amount of variation, we performed a geometric morphometric analysis. Then, in order to analyse if there could be a relationship between these differences and dietary preferences, we measured the mechanical advantage of the mandibles through the lengths of four structures involved in biting. 


\section{MATERIAL AND METHODS}

\subsection{Samples}

To carry out the analysis, 12 mandibles of Cricetodon aff. aureus and Megacricetodon minor (Table 1) were photographed from the Bayerische Staatssammlung für Paläontologie und Geologie (SNSB-BSPG; Munich, Germany). The specimens were photographed using the binocular microscope Leica 50x and its associated software from the same institution and a 12.3 megapixels Nikon D300S camera equipped with a Nikon $105 \mathrm{~mm}$ f/2.8G IFED lens.

Table 1. List of mandibles studied of Megacricetodon minor from Goldberg and Cricetodon aff. aureus from Steinberg.

\begin{tabular}{ll}
\hline Species & Catalogue number \\
\hline Megacricetodon minor & SNSB-BSPG 1966 XXXIV-3493 \\
& SNSB-BSPG 1966 XXXIV-3498 \\
& SNSB-BSPG 1966 XXXIV-3516 \\
& SNSB-BSPG 1966 XXXIV-3528 \\
& SNSB-BSPG 1966 XXXIV-3539 \\
& SNSB-BSPG 1966 XXXIV-3546 \\
& SNSB-BSPG 1966 XXXIV-3555 \\
\hline Cricetodon aff. aureus & SNSB-BSPG 1970 XVIII-8060 \\
& SNSB-BSPG 1970 XVIII-8062 \\
& SNSB-BSPG 1970 XVIII-8063 \\
& SNSB-BSPG 1970 XVIII-8067 \\
& SNSB-BSPG 1970 XVIII-8068 \\
\hline
\end{tabular}

\subsection{Morphometric and statistical analyses}

To characterize the shape of the mandibles, we choose the lateral view and the labial region following Bi et al. (2008), Anderson et al. (2014), Astúa et al. (2015), Fabre et al. (2017), and Menegaz \& Ravosa (2017). In order to eliminate the asymmetry between right and left mandibles, we rotate the pictures of the left mandibles, as if they were reflected in a mirror, and processed them as right mandibles. We included only the mandibles for which all structures were complete (Fig.1). Eighteen landmarks (Fig. 2, Table 2) were used to describe the shape of the mandible. Landmarks were digitized using tpsDig2 2.32 (Rohlf, 2010) and a Generalized Procrustes Analysis (GPA) was performed on the landmarks using MorphoJ (Klingenberg, 2011). These Procrustes-transformed landmarks were used to generate a covariance matrix with which we performed a Principal Component Analysis (PCA).

Following Anderson et al. (2014) and Fabre et al. (2017), we measured the mechanical advantage (MA,
Table 2. Landmarks locations in the hemimandible. Lm: landmark. Location of landmarks proposed by Anderson et al. (2014) and Fabre et al. (2017).

\begin{tabular}{|c|c|}
\hline Lm & Location \\
\hline Lm1 & $\begin{array}{l}\text { Most antero-ventral point of alveolus of the } \\
\text { incisor }\end{array}$ \\
\hline Lm2 & Most antero-dorsal point of alveolus of the incisor \\
\hline Lm3 & $\begin{array}{l}\text { Point at the maximum of curvature of the } \\
\text { diastema }\end{array}$ \\
\hline Lm4 & $\begin{array}{l}\text { Anterior point of the alveolar margin of the tooth } \\
\text { row }\end{array}$ \\
\hline Lm5 & $\begin{array}{l}\text { Boundary between the second and third lower } \\
\text { molars }\end{array}$ \\
\hline Lm6 & $\begin{array}{l}\text { Intersection between the ascending ramus and the } \\
\text { posterior part of the lower third molar }\end{array}$ \\
\hline $\operatorname{Lm} 7$ & Dorsal-most point of the coronoid process \\
\hline Lm8 & $\begin{array}{l}\text { Point at the maximum of concavity between the } \\
\text { coronoid and the articular processes }\end{array}$ \\
\hline Lm9 & Antero-dorsal side of the articular condyle \\
\hline $\mathrm{Lm} 10$ & Dorsal-most point of the articular condyle \\
\hline Lm11 & Posterior-most point of the articular condyle \\
\hline Lm12 & Ventral-most point of the articular condyle \\
\hline Lm 13 & $\begin{array}{l}\text { Point at the maximum of concavity between the } \\
\text { articular and the angular processes }\end{array}$ \\
\hline Lm14 & Posterior-most point of the angular process \\
\hline Lm15 & Ventral-most point of the angular process \\
\hline Lm16 & $\begin{array}{l}\text { Maximum point of concavity in the dorsal } \\
\text { mandibular region }\end{array}$ \\
\hline Lm17 & $\begin{array}{l}\text { Ventral-most point of the front lower part of the } \\
\text { mandible }\end{array}$ \\
\hline $\mathrm{Lm} 18$ & $\begin{array}{l}\text { Point of maximum of curvature of the deep } \\
\text { masseteric insertion }\end{array}$ \\
\hline
\end{tabular}

efficiency of the mandible to transmit the muscular forces to the bite point) and the mechanical potential (MP, estimation of the biting force). These mechanicals advantages and potentials are ratios based on lengths measured in the photographs of the mandibles using the ruler tool of Photoshop (Fig. 2). MA is the ratio between inlever or the distance from the jaw point to the point of muscle attachment and outlever or the distance from the jaw point to the bite point (Fig. 2). We calculated four MA ratios: $\mathrm{MA}_{\mathrm{T} / \mathrm{In}}$ (inlever: temporal; outlever: incisor length), $\mathrm{MA}_{\mathrm{Ms} / \mathrm{In}}$ (inlever: masseter length; outlever: incisor length), $\mathrm{MA}_{\mathrm{T} / \mathrm{Mo}}$ (inlever: temporal length; outlever: molar length) and $\mathrm{MA}_{\mathrm{Ms} M \mathrm{Mo}}$ (inlever: masseter length; outlever: molar length) (see Table 3). It can be observed in Figure 2 that most of the measured lengths have an origin and an end that correspond to a landmark; this fact essays the interpretation between the PCA and the ratios. Only the length for the distance between the condylar process and the lower first molar does not have a correspondence with 


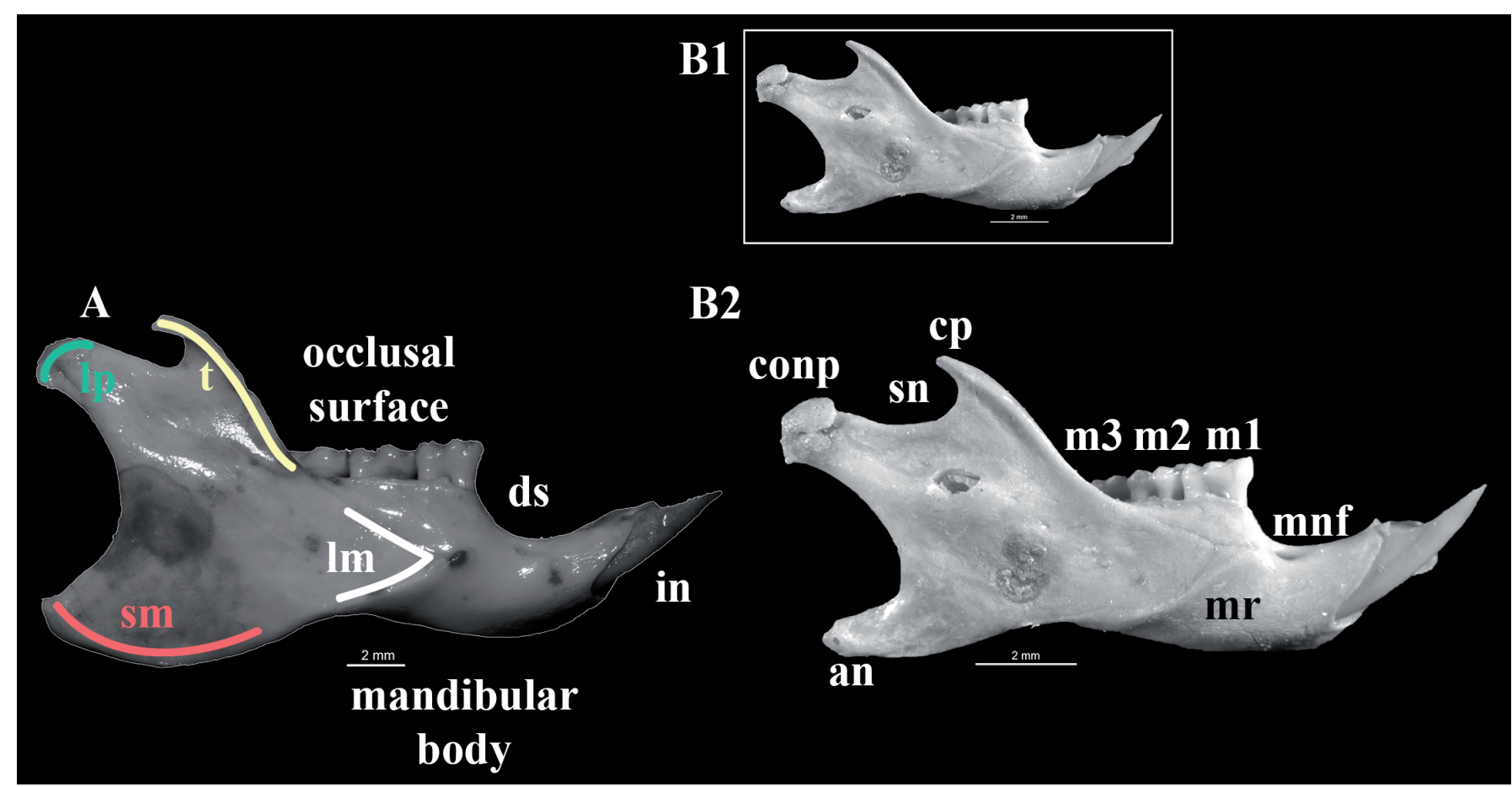

Figure 1. Cricetodon aff. aureus (SNSB-BSPG 1970 XVIII-8063) (a) and Megacricetodon minor (SNSB-BSPG 1966 XXXIV-3516) (b) at different scale to visualize the size differences. The nomenclature of the skeletal regions is the proposed by Mein \& Freudenthal (1971a) and Bi et al. (2008). The musculature nomenclature is from Atchley et al. (1985). Abbreviations: an, angular process; cp, coronoid process; conp, condylar process; ds, diastema; mnf, mental foramen; mr, masseteric ridge; in, incisor; m1, m2, m3, first, second, third lower molars; sn, sigmoid notch. Coloured lines indicate the insertions for the muscles: lm, lateral masseter; lp, lateral pterygoid, sm, superficial masseter, $t$, temporal muscle.
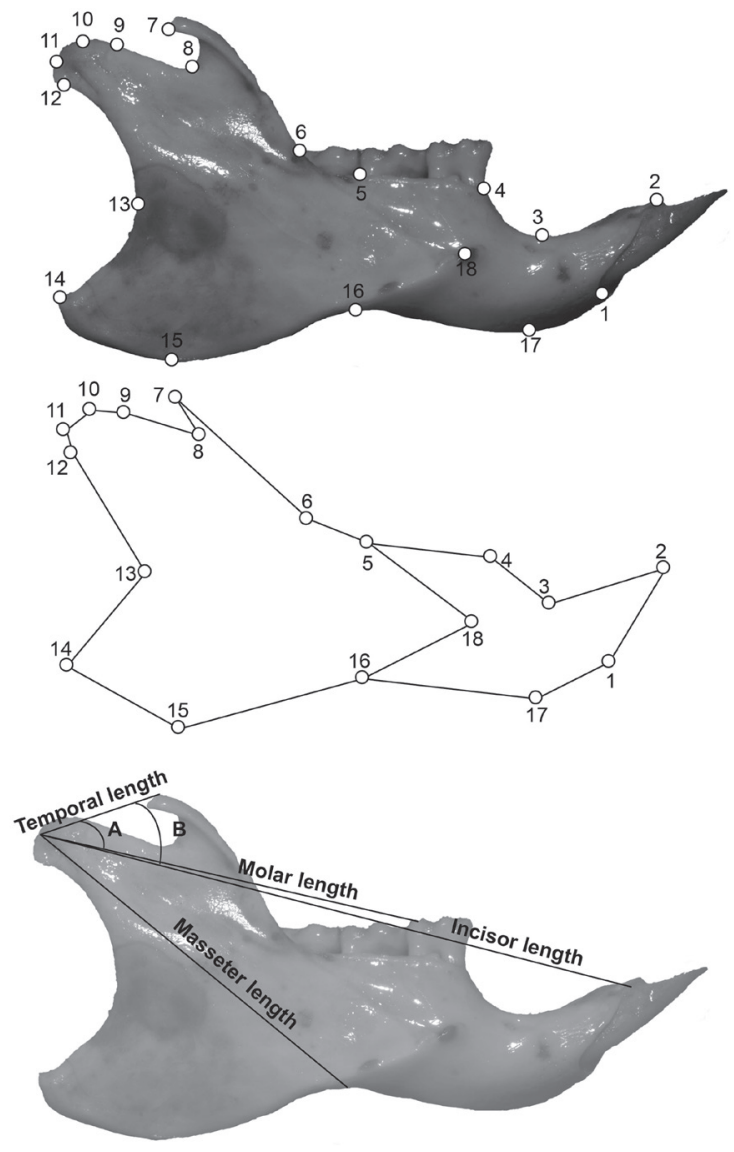

any landmark. Anderson et al. (2014) measured the incisor length from the condylar process to the incisor tip. In our sample, some of the specimens do not present the incisor or this presents alterations in its position. Therefore, we use the anterior point of the alveolus of the incisor as the end of the incisor length. To calculate the MP firstly, we obtained the angle between the molar length and the temporal length (angle A) and between the incisor length and temporal length (angle B). Secondly, we calculated the two force angles (FA) through: radian $\left(90^{\circ}\right)$-radian(angle $\mathrm{A}$ or B). Finally, the $\mathrm{MP}_{\mathrm{Mo}}=\mathrm{MA}_{\mathrm{T} / \mathrm{Mo}} \mathrm{x} \operatorname{cosine}(\mathrm{FA}-\mathrm{A})$ and $\mathrm{MP}_{\mathrm{In}}=\mathrm{MA}_{\mathrm{T} / \mathrm{In}} \operatorname{cosine}(\mathrm{FA}-\mathrm{B})$ (Fig. 2; Table 3). With these ratios, we performed boxplots in order to visualize the variation of the sample among these species. To confirm if

Figure 2. Top: digitalized landmarks (see Table 3) of Cricetodon aff. aureus (SNSB-BSPG 1970 XVIII-8063). Middle: wireframe of this specimen used for visualized geometric variation of the shape. Bottom: lengths and angles measured on digital photographs. Temporal length: from LM11 to LM7; molar length: from LM11 to the tip of hipoconid of the lower first molar; incisor length: from LM11 to LM2; masseter length: from LM11 to LM17. 
there were significant differences between the two species, we performed a non-parametric Mann-Whitney test due to the limited sample size.

Table 3. List of ratios obtained from the linear measurements.

\begin{tabular}{|c|c|c|c|c|c|c|c|}
\hline Specimen & Species & $\mathbf{M} \mathbf{A}_{\mathrm{T} / \mathrm{n}}$ & $\mathbf{M A}_{\mathrm{Ms} / \mathrm{In}}$ & $\mathbf{M A}_{\mathrm{T} / \mathrm{M}_{0}}$ & $\mathbf{M A}_{\mathrm{Ms} / \mathbf{M}_{0}}$ & $\mathbf{M P}_{\text {In }}$ & $\mathbf{M P}_{\mathrm{Mo}}$ \\
\hline 3493 & \multirow{7}{*}{ M. minor } & 0.229 & 0.532 & 0.356 & 0.827 & 0.120 & 0.185 \\
\hline 3498 & & 0.269 & 0.536 & 0.413 & 0.825 & 0.121 & 0.177 \\
\hline 3516 & & 0.275 & 0.565 & 0.415 & 0.853 & 0.138 & 0.188 \\
\hline 3528 & & 0.293 & 0.550 & 0.430 & 0.806 & 0.139 & 0.194 \\
\hline 3539 & & 0.259 & 0.549 & 0.384 & 0.815 & 0.172 & 0.233 \\
\hline 3546 & & 0.266 & 0.531 & 0.390 & 0.780 & 0.145 & 0.206 \\
\hline 3555 & & 0.251 & 0.575 & 0.358 & 0.822 & 0.145 & 0.199 \\
\hline 8060 & \multirow{5}{*}{$\begin{array}{l}\text { C. aff. } \\
\text { aureus }\end{array}$} & 0.158 & 0.609 & 0.253 & 0.973 & 0.084 & 0.133 \\
\hline 8062 & & 0.237 & 0.584 & 0.385 & 0.949 & 0.099 & 0.163 \\
\hline 8063 & & 0.197 & 0.617 & 0.312 & 0.982 & 0.101 & 0.157 \\
\hline 8067 & & 0.238 & 0.609 & 0.385 & 0.986 & 0.089 & 0.144 \\
\hline 8068 & & 0.205 & 0.594 & 0.328 & 0.951 & 0.119 & 0.186 \\
\hline
\end{tabular}

\section{RESULTS AND DISCUSSION}

We computed a PCA using the landmark dataset and plot the results in a graph (Fig. 3). The PCA resumes the total variance into a few dimensions that allow us to explore the landmark position variation of the sample. The percentage of variance that gathers the first two principal components

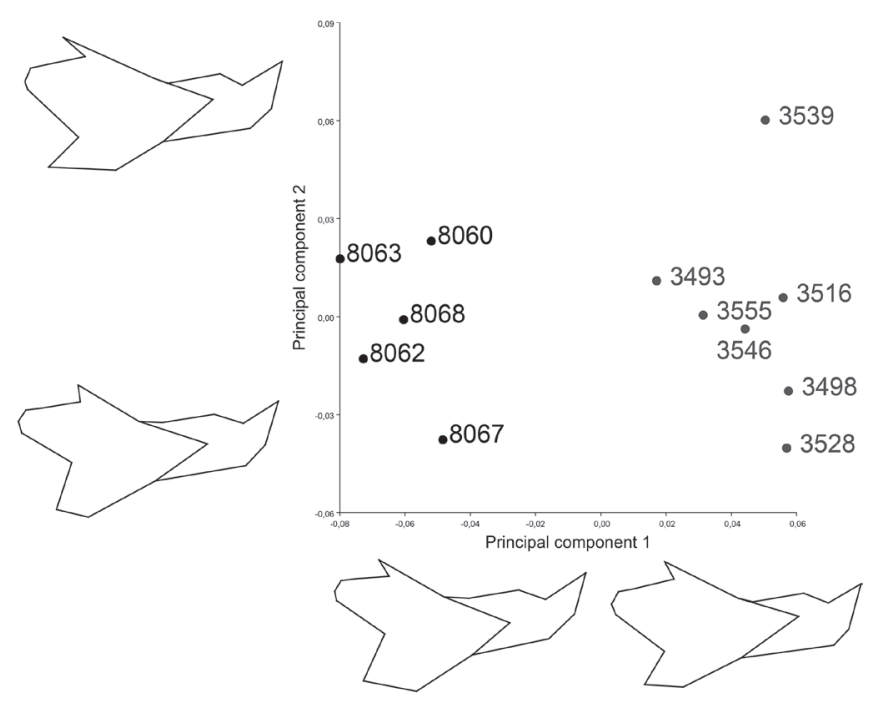

Figure 3. PCA and morphological transformation along the axis. Black dots represent Cricetodon aff. aureus and grey dots denote Megacricetodon minor. Numbers are the abbreviations of the catalogue numbers. Wireframes are representing the extreme morphology for each axis.
( $\mathrm{PC} 1$ and $\mathrm{PC} 2$ ) is $70.7 \%$. To represent the variation of the landmarks along the axis, we added the wireframes configurations of the extreme configuration (Fig. 3). The PC1 ordered the sample in two different groups characterized by a greater development of the angular process and lower development of the condylar process in Cricetodon aff. aureus and a greater development of the condylar process and more anterior position of the lower masseter in Megacricetodon minor. The PC2 gathers the morphological variation of the coronoid process from forms with lower development on it (negative values) to forms with greater development on this process. The $\mathrm{PC} 1$ gathers the interspecific variation of the sample establishing two different groups. The PC2 gathers the intraspecific variation within the two groups. The rest of the variance $(29.3 \%)$ is mostly distributed among the PC3-PC6, which distributes the sample according to morphological differences without a clear relationship with biomechanical features.

This intraspecific variation could be related to the findings of Anderson et al. (2014), which described that part of the morphological variation is a result of the adaptive plasticity of the populations in response to environmental changes. To explore this morphological variability, we performed the biomechanical ratios by boxplots (Fig. 4). The results show differences between the species for the different ratios. To confirm that there are significant differences between the analysed ratios of the mandibles, we performed a Mann-Whitney analysis. The results indicate that all ratios, but one show significant differences (Fig. 4).

It can be noted on the PCA (Fig. 3) that we have been able to quantify morphological differences among these species. Unlike the descriptions proposed by Mein \& Freudenthal (1971a) based on morphological variation of the mandible, the geometric morphometric analysis allows us to establish the amount of variation among the different parts of the mandibles. It is worth noting that the greater morphological variation is related to skull structures that are tightly related to biomechanical features (as angular and coronoid processes and low masseter insertion) (Satoh, 1999; Cox et al., 2012; Anderson et al., 2014; Fabre et al., 2017).

Although diet is traditionally inferred based on molar morphologies (Coillot et al., 2013; Lazzari et al., 2015), there are other proxies that could be used to deduce the diet of these cricetids rodents, such as the mechanical advantage and potential (Anderson et al., 2014; Fabre et al., 2017). Boxplots (Fig. 4) show that Megacricetodon minor presents higher mechanical advantage values in the ratios $\mathrm{MA}_{\mathrm{T} / \mathrm{n}}$ and $\mathrm{MA}_{\mathrm{T} / \mathrm{Mo} \text {. }}$ These results coincide with those of the PCA in which the PC1 describes the mandibles of M. minor as mandibles with a post-displaced condylar process. Higher values of the length between the condylar and coronoid process result in an increase in the values of $\mathrm{MA}_{\mathrm{T} / \mathrm{n}}$ and $\mathrm{MA}_{\mathrm{T} / \mathrm{Mo}}$. The result of $\mathrm{MA}_{\mathrm{T} / \mathrm{Mo}}$ must be interpreted 
$\mathrm{P}<0,0148$

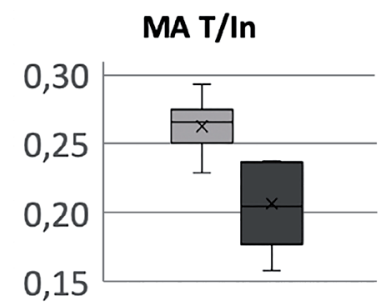

$\mathrm{P}<0,0735$

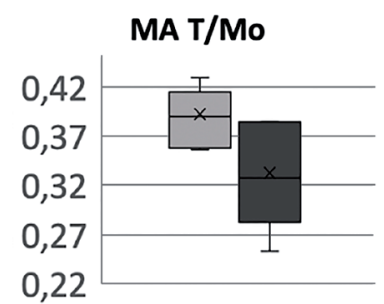

$\mathrm{P}<0,0057$

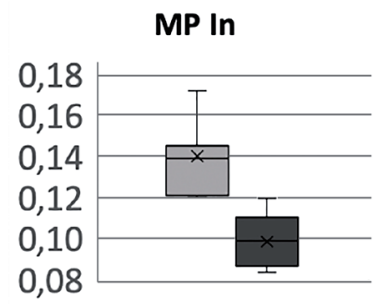

Megacricetodon minor
$\mathrm{P}<0,0057$
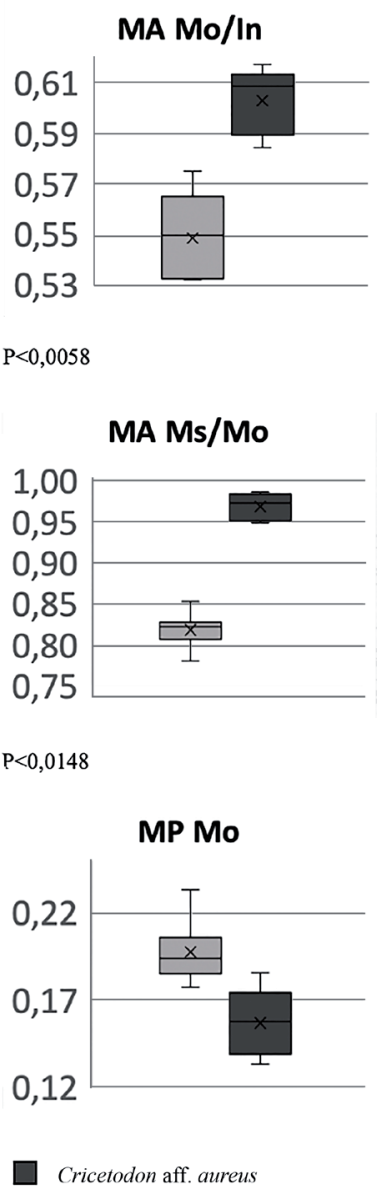

Figure 4. Boxplots of mechanical advantage and potential. On the top of the plots there are the p-values of the MannWhitney analysis for each ratio.

with caution since the statistical analysis does not show significant differences between the species in this ratio. In sum, M. minor possesses post-displaced condylar process and narrower masseteric areas; these position and reduction thus likely favour a quick jaw closure and weaker biting forces compatible with a faunivore diet (Fabre et al., 2017). The morphological pattern shown by the mandible of M. minor is similar to extant faunivore rodents as the tribe Hidromiyini (see Helgen, 2005; Fabre et al., 2017). As we have mentioned above, traditionally, dentition has been the proxy to infer the diet of the mammals. Dentition of Megacricetodon has been described as brachyodont and mesodont molar with bunodont dental pattern (van Dam \& Weltje, 1999; Fejfar et al., 2011) typical of an omnivore organism. However, and taking into account the morphometric and biomechanical analysis, the morphological patter of M. minor could fit to an omnivore diet with faunivore preferences attending to the biomechanical behavior of its mandibles.
Cricetodon aff. aureus presents significant higher values in $\mathrm{MA}_{\mathrm{Ms} / \mathrm{n}}$ and $\mathrm{MA}_{\mathrm{Ms} / \mathrm{Mo}}$ related to the greater development of the angular process and its relative position with the condylar process indicative of the biting strength. The values of the mechanical potential are significantly higher in M. minor. The results of these ratios can be related with the post-displaced condylar process that triggers an increase in the ratios values. The results of the PC1 combined with the ratios of the mandibles show that $C$. aff aureus presents a wider angular process and masseteric ridge areas that could be defined as a mandible with a slower closure (lower values of $\mathrm{MA}_{\mathrm{T} / \mathrm{n}}$ and $\mathrm{MA}_{\mathrm{T} / \mathrm{Mo}}$ ) and stronger biting force (higher values of $\mathrm{MA}_{\mathrm{Ms} / \mathrm{In}}$ and $\mathrm{MA}_{\mathrm{Ms} / \mathrm{Mo}}$ ) compatible with a harder diet (Fabre et al., 2017). This mandibular morphology is comparable with extant rodent species to which a herbivorous diet is attributed as Hapalomys, Melomys and Sundamys among others (Camacho-Sánchez et al., 2017; Fabre et al., 2017; Gómez Cano et al., 2017). These results coincide with the traditional interpretation of the molar pattern of Cricetodon, described as cricetids with buno-lophodont molars and som high-crowned pattern in some of the species (De Bruijn \& Ünay, 1996; van Dam \& Weltje, 1999; Durgut \& Ünay, 2016). This dental pattern and the mandibular morphology could correspond to a more herbivore organism.

As it is evident on the PC2, M. minor presents a greater amount of morphological variability, which could be related to the plasticity as defined in Anderson et al. (2014): "non-heritable morphological variation, enables organisms to modify the shape of their skeletal tissues in response to varying environmental stimuli". This plasticity could be the origin of the ecological success of this ubiquitous species, which has been recorded in many fossil sites along Europe during lower to upper Miocene (Daams et al., 1999; Oliver \& Peláez-Campomanes, 2013).

\section{CONCLUSSIONS}

2D geometric morphometric analysis has revealed as a tool to quantify the mandibular shape of $C$. aff. aureus and $M$. minor, and has let us to establish morphological differences among these species and determine a morphological pattern for each species. We could determine the regions that gather the greatest amount of variation: condylar and angular processes and lower masseter. These regions are fundamental to explain the biomechanical behaviour of the mandibles. Due to this fact, for the first time, a biomechanical analysis has been performed in fossil cricetids mandibles by the measurements of different ratios based on the length of these key structures. The results showed that Megacricetodon minor and Cricetodon aff. aureus present significant differences in most of the 
values of the mechanical advantages and potentials of their mandibles and therefore they should develop different forces and speeds biting. The robust mandibular pattern that defines $C$. aff. aureus favours slower closure of the mandible but stronger biting forces of the molar region. This, together with its molar pattern could be indicating an herbivore diet. The narrow mandibular patter that defines M. minor favours faster closure of the mandible and weaker biting forces of the molar region. These characteristics and the bunodont pattern of its molar could be compatible with an omnivore diet with faunivore preferences. These mechanical characteristics could indicate different diets of these species. However, further studies (increasing the sample with extant rodents with a defined diet, adding other related species in other fossil sites) are required in order to establish more concrete results.

\section{ACKNOWLEDGMENT}

We are very grateful to Sociedad Española de Paleontología for giving us the possibility to visit the Bayerische Staatssammlung für Paläontologie und Geologie to study the material thanks to the AJISEP grants 2018. Also, we are very grateful to Gertrud Rössner (BSPG) for access to the collections of Goldberg and Steinberg. Furthermore, we greatly appreciate Sergio Vargas (BSPG) for their help during the stay in Munich. We thank the reviewers J. Agustí and O. Maridet for their critical comments and contributions, which greatly improved the manuscript. The labour of the Editor Gonzalo Jiménez Moreno is greatly appreciated. This is a contribution of the Research Group Team 910607 on Evolution of Cenozoic Mammals and Continental Palaeoenvironments of the Complutense University of Madrid. This study was also supported by the Spanish Economy and Competitiveness Ministry research project PGC2018 094955-A-100 and PGC2018094122-B-100.

\section{REFERENCES}

Aguilar, J.-P. 1995. Evolution de la lignée Megacricetodon collongensis-Megacricetodon roussillonensis (Cricetidae, Rodentia, Mammalia) au cours du Miocène inférieur et moyen dans le sud de la France. Palaeovertebrata, 24, 1-45.

Anderson, P.S.L., Renaud, S. \& Rayfield, E.J. 2014. Adaptive plasticity in the mouse mandible. BMC Evolutionary Biology, 14, 85; doi: 10.1186/1471-2148-14-85.

Andresen, P.R., Bookstein, F.L., Conradsen, K., ErsbØll, B., Marsh, J. \& Kreiborg, S. 2000. Surface-bounded growth modeling applied to human mandibles. IEEE
Transactions on Medical Imaging, 19, 1053-1063; doi: 10.1109/42.896780.

Arp, G. 2006. Sediments of the Ries Crater Lake (Miocene, Southern Germany). Schriftenreihe der deutschen Gesellschaft für Geowissenschaften, 45, 213-236; doi: 10.23689/fidgeo-2785.

Astúa, D., Bandeira, I. \& Geise, L. 2015. Cranial morphometric analyses of the cryptic rodent species Akodon cursor and Akodon montensis (Rodentia, Sigmodontinae). Oecologia Australis, 19, 143-157; doi: 10.4257/oeco.2015.1901.09.

Atchley, W.R. 1983. Some genetic aspects of morphometric variation. In: Numerical Taxonomy (ed. Felsenstein, J.). NATO ASI Series, Springer, Berlin, Heidelberg. 346-363.

Atchley, W.R. 1993. Genetic and developmental aspects of variability in the mammalian mandible. In: The Skull. Volume 1 (eds Hanken, J. \& Hall, B.K.). The University of Chicago Press, Chicago and London. 207-247.

Atchley, W.R., Plummer, A.A. \& Riska, B. 1985. Genetics of mandible form in the mouse. Genetics, 111, 555-577.

Baltanás, A., Brauneis, W., Danielopol, D.L. \& Linhart, J. 2003. Morphometric methods for applied ostracodology: tools for outline analysis of nonmarine ostracodes. The Paleontological Society Papers, 9, 101-118; doi: 10.1017/ S1089332600002175.

Bastir, M., Rosas, A. \& Kuroe, K. 2004. Petrosal orientation and mandibular ramus breadth: evidence for an integrated petroso-mandibular developmental unit. American Journal of Physical Anthropology, 123, 340-350; doi: 10.1002/ ajpa.10313.

Bi, S., Meng, J. \& Wu, W. 2008. A new species of Megacricetodon (Cricetidae, Rodentia, Mammalia) from the middle Miocene of northern Junggar Basin, China. American Museum Novitates, 1-23; doi: 10.1206/0003-0082(2008)3602[1:ANSOMC]2.0.CO;2.

Bookstein, F.L. 1996. Combining the tools of geometric morphometrics. In: Advances in Morphometrics (eds. Marcus, L.F., Corti, M., Loy, A., Naylor, G.J.P. \& Slice, D.E.). NATO ASI Series, Springer, Boston, MA.131-151.

Camacho-Sanchez, M., Leonard, J.A., Fitriana, Y., Tilak, M.K. \& Fabre, P.H. 2017. The generic status of Rattus annandalei (Bonhote, 1903) (Rodentia, Murinae) and its evolutionary implications. Journal of Mammalogy, 98, 1340-1355; doi: 10.1093/jmammal/gyx081.

Carro-Rodríguez, P.M., López-Guerrero, P. \& Álvarez-Sierra, M.Á. 2018. Fourier analysis applied to Cricetodon and Hispanomys (Rodentia, Mammalia): its use as a taxonomical criterion. Historical Biology, 1-24; doi: 10.1080/08912963.2018.1472254.

Casanovas-Vilar, I. \& van Dam, J. 2013. Conservatism and adaptability during squirrel radiation: what is mandible shape telling us? PLoS ONE 8(4): e61298; doi: 10.1371/ journal.pone.0061298. https://doi.org/10.1371/journal. pone.0061298.

Coillot, T., Chaimanee, Y., Charles, C., Gomes-Rodrigues, H., Michaux, J., Tafforeau, P., Vianey-Liaud, M., Viriot, L. \& Lazzari, V. 2013. Correlated changes in occlusal pattern and diet in stem Murinae during the onset of the 
radiation of the old world rats and mice. Evolution, 67, 3323-3338; doi: 10.1111/evo.12172.

Cox, P.G., Rayfield, E.J., Fagan, M.J., Herrel, A., Pataky, T.C. \& Jeffery, N. 2012. Functional evolution of the feeding system in rodents. PLoS One, 7(4), e36299; doi: 10.1371/ journal.pone.0036299.

Daams, R., van der Meulen, A.J., Álvarez Sierra, M.A., Peláez-Campomanes, P., Calvo, J.P., Alonso Zarza, M.A. \& Krijgsman, W. 1999. Stratigraphy and sedimentology of the Aragonian (Early to Middle Miocene) in its type area (North-Central Spain). Newsletters on Stratigraphy, 37, 103-139; doi: 10.1127/nos/37/1999/103.

De Bruijn, H. \& Ünay, E. 1996. On the evolutionary history of the Cricetodontini from Europe and Asia Minor and its bearing on the reconstruction of migrations and the continental biotope during the Neogene. In: The Evolution of Western Eurasian Neogene Mammal Faunas (eds Bernor, R.L. \& Fahlbusch, V.). Columbia University Press, New York. 227-234.

Durgut, N.Ç., \& Engin, Ü. 2016. Cricetodontini from the early Miocene of Anatolia. Bulletin of the Mineral Research and Exploration, 152, 85-119; doi: 10.19111/bmre.35767.

Fabre, P.H., Herrel, A., Fitriana, Y., Meslin, L. \& Hautier, L. 2017. Masticatory muscle architecture in a water-rat from Australasia (Murinae, Hydromys) and its implication for the evolution of carnivory in rodents. Journal of Anatomy, 231, 380-397; doi: 10.1111/joa.12639.

Fahlbusch, V. 1964. Die Cricetiden (Mamm.) der Oberen Süßwasser-Molasse Bayerns. Bayerische Akademie der Wissenschaften; mathematisch-naturwissenschaftliche Klasse, Abhandlungen, neue Folge, 118, 1-136.

Fejfar, O., Heinrich, W.D., Kordos, L. \& Maul, L.C. 2011. Microtoid cricetids and the early history of arvicolids (Mammalia, Rodentia). Palaeontologia Electronica, 14, $1-38$.

Freudenthal, M. \& Fahlbusch, V. 1969. Cricetodon minus Lartet, 1851 (Mammalia, rodentia): request for a decision on interpretation. Bulletin of Zoological Nomenclature, 25, 5; doi: 10.5962/bhl.part.23988.

Göhlich, U.B. \& Ballmann, P.A. 2013. A new barn owl (Aves: Strigiformes: Tytonidae) from the Middle Miocene of the Nördlinger Ries (Germany) with remarks on the history of the owls. Paleontological Research-Proceedings of the 8th International Meeting of the Society of Avian Palaeontology and Evolution. 103-122.

Gómez Cano, A.R., Kimura, Y., Blanco, F., Menéndez, I., Álvarez-Sierra, M.Á. \& Hernández Fernández, M. 2017. Ecomorphological characterization of murines and nonarvicoline cricetids (Rodentia) from south-western Europe since the latest Middle Miocene to the Mio-Pliocene boundary (MN 7/8-MN13). PeerJ, 5, e3646; doi: 10.7717/ peerj.3646.

Hall, B.K. 2003. Descent with modification: the unity underlying homology and homoplasy as seen through an analysis of development and evolution. Biological Reviews, 78, 409-433; doi: 10.1017/s1464793102006097.

Heizmann, E.P.J. \& Fahlbusch, V. 1983. Die mittelmiozäne Wirbeltierfauna vom Steinberg (Nördlinger Ries). Eine
Übersicht. Mitteilungen der Bayerischen Staatssammlung für Paläontologie und historische Geologie, 23, 83-93.

Helgen, K.M. 2005. The amphibious murines of New Guinea (Rodentia, Muridae): the generic status of Baiyankamys and description of a new species of Hydromys. Zootaxa, 913, 1-20; doi: 10.11646/zootaxa.913.1.1.

Kendall, D.G. 1977. The diffusion of shape. Advances in Applied Probability, 9, 428-430; doi: 10.2307/1426091.

Klingenberg, C.P. 2008. Morphological integration and developmental modularity. Annual Review of Ecology, Evolution, and Systematics, 39, 115-132; doi: 10.1146/ annurev.ecolsys.37.091305.110054.

Klingenberg, C.P. 2011. MorphoJ: an integrated software package for geometric morphometrics. Molecular Ecology Resources, 11, 353-357; doi: 10.1111/j.17550998.2010.02924.x.

Klingenberg, C.P. 2016. Size, shape, and form: concepts of allometry in geometric morphometrics. Development Genes and Evolution, 226, 113-137; doi: 10.1007/s00427016-0539-2.

Kono, K., Tanikawa, C., Yanagita, T., Kamioka, H. \& Yamashiro, T. 2017. A novel method to detect 3D mandibular changes related to soft-diet feeding. Frontiers in Physiology, 8, 567; doi: 10.1007/s00427-016-0539-2.

Lartet, E. 1851. Notice sur la Colline de Sansan, Suivie d'une Récapitulation des Diverses Espèces d'Animaux Vertébrés Fossiles, Trouvés soit à Sansan, soit dans d'Autres Gisements du Terrain Tertiaire du Miocène dans le Bassin Sous-Pyrénéen. impr. JA Portes.

Lazzari, V., Guy, F., Salais, P.E., Euriat, A., Charles, C., Viriot, L., Tafforeau, P. \& Michaux, J. 2015. Convergent evolution of molar topography in Muroidea (Rodentia, Mammalia): connections between chewing movements and crown morphology. In: Evolution of the Rodents: Advances in Phylogeny, Functional Morphology and Development (eds Cox, P.G. \& Hautier, L.). 448-477.

López-Guerrero, P., García-Paredes, I. \& Álvarez-Sierra, M.Á. 2013. Revision of Cricetodon soriae (Rodentia, Mammalia), new data from the middle Aragonian (middle Miocene) of the Calatayud-Daroca Basin (Zaragoza, Spain). Journal of Vertebrate Paleontology, 33, 169-184; doi: $10.2307 / 23361080$.

López-Guerrero, P., García-Paredes, I., Álvarez-Sierra, M.Á. \& Peláez-Campomanes, P. 2014. Cricetodontini from the Calatayud-Daroca Basin (Spain): A taxonomical description and update of their stratigraphical distributions. Comptes Rendus Palevol, 13, 647-664; doi: 10.1016/j. crpv.2014.07.002.

Mein, P. 1975: Biozonation du Néogène Méditerranéen à partir des Mammifères. Proceedings of the $V^{l^{\text {th }}}$ Congress. R.C.M.N.S. Bratislava, 2, 18.

Mein, P. \& Freudenthal, M. 1971a. Une nouvelle classification des Cricetidae (Mam. Rod.) du Tertiaire d'Europe. Scripta Geologica, 2, 1-37.

Mein, P. \& Freudenthal, M. 1971b. Les Cricetidae (Mammalia, Rodentia) du Néogène moyen de Vieux-Collonges. Part 1. Le genre Cricetodon Lartet, 1851. Scripta Geologica, $5,1-51$. 
Menegaz, R.A. \& Ravosa, M. J. 2017. Ontogenetic and functional modularity in the rodent mandible. Zoology, 124, 61-72; doi: 10.1016/j.zool.2017.05.009.

Oliver Pérez, A., López Guerrero, P. \& Peláez-Campomanes, P. 2008. Primer representante del género Megacricetodon de la Cuenca de Calatayud-Daroca (Zaragoza, España). Palaeontologica Nova, 8, 317-329.

Oliver, A. \& Peláez-Campomanes, P. 2013. Megacricetodon vandermeuleni sp. nov. (Rodentia, Mammalia), from the Spanish Miocene: a new evolutionary framework for Megacricetodon. Journal of Vertebrate Paleontology, 33, 943-955; doi: 10.1080/02724634.2013.743896.

Oxnard, C. \& O’Higgins, P. 2009. Biology clearly needs morphometrics. Does morphometrics need biology? Biological Theory, 4, 84-97; doi: 10.1162/biot.2009.4.1.84.

Prieto, J., Böhme, M. \& Gross, M. 2010. The cricetid rodents from Gratkorn (Austria, Styria): a benchmark locality for the continental Sarmatian sensu stricto (late Middle Miocene) in the Central Paratethys. Geologica Carpathica, 61, 419-436; doi: 10.2478/v10096-010-0025-0.

Prieto, J. \& Rummel, M. 2016. Some considerations on small mammal evolution in Southern Germany, with emphasis on Late Burdigalian-Earliest Tortonian (Miocene) cricetid rodents. Comptes Rendus Palevol, 15, 837-854; doi: 10.1016/j.crpv.2016.08.002.

Rachl, R. 1983. Die Chiroptera (Mammalia) aus den mittelmiozänen Kalken des Nördlinger Rieses (Süddeutschland). Ph.D. Thesis. Ludwig-MaximiliansUniversität München.

Renaud, S., Alibert, P. \& Auffray, J.C. 2012. Modularity as a source of new morphological variation in the mandible of hybrid mice. BMC Evolutionary Biology, 12, 141; doi: 10.1186/1471-2148-12-141.

Richtsmeier, J.T., Burke Deleon, V. \& Lele, S.R. 2002. The promise of geometric morphometrics. American Journal of Physical Anthropology, 119, 63-91; doi: 10.1002/ ajpa.10174.

Rohlf, F.J. \& Marcus, L.F. 1993. A revolution morphometrics. Trends in Ecology \& Evolution, 8, 129-132; doi: 10.1016/0169-5347(93)90024-J.

Rohlf, F.J. 2010. Software tpsDig2, version 2.32. State University of New York, New York. 11794-5245.

Rummel, M. 2000. Die Cricetodontini aus dem Miozän von Petersbuch bei Eichstätt. Die Gattung Cricetodon. Senckenbergiana Lethaea, 80, 149-171; doi: 10.1007/ BF03043668.

Satoh, K. 1999. Mechanical advantage of area of origin for the external pterygoid muscle in two murid rodents, Apodemus speciosus and Clethrionomys rufocanus. Journal of Morphology, 240, 1-14; di: 10.1002/(SICI)10974687(199904)240:1<1::AID-JMOR1>3.0.CO;2-D.
Siver, P.A., Wolfe, A.P., Rohlf, F.J., Shin, W. \& Jo, B.Y. 2013. Combining geometric morphometrics, molecular phylogeny, and micropaleontology to assess evolutionary patterns in $M$. allomonas (Synurophyceae: Heterokontophyta). Geobiology, 11, 127-138; doi: 10.1111/gbi.12023.

Tokita, M., Yano, W., James, H.F. \& Abzhanov, A. 2017. Cranial shape evolution in adaptive radiations of birds: comparative morphometrics of Darwin's finches and Hawaiian honeycreepers. Philosophical Transactions of the Royal Society B, 372, 20150481; doi: 10.1098/ rstb.2015.0481.

Toro Ibacache, M.V., Manríquez Soto, G. \& Suanzo Galdames, I. 2010 Morfometría geométrica y el estudio de las formas biológicas: de la morfología descriptiva a la morfología cuantitativa. International Journal of Morphology, 28, 977-990; doi: 10.4067/S0717-95022010000400001.

van Dam, J.A. \& Weltje, G.J. 1999. Reconstruction of the Late Miocene climate of Spain using rodent palaeocommunity successions: an application of end-member modelling. Palaeogeography, Palaeoclimatology, Palaeoecology, 151, 267-305; doi: 10.1016/S0031-0182(99)00015-2.

van Dam, J.A., Krijgsman, W., Abels, H.A., Álvarez-Sierra, M.Á., García-Paredes, I., López-Guerrero, P., PeláezCampomanes, P. \& Ventra, D. 2014. Updated chronology for middle to late Miocene mammal sites of the Daroca area (Calatayud-Montalbán Basin, Spain). Geobios, 74, 325-334; doi: 10.1016/j.geobios.2014.07.002.

van der Meulen, A.J., García-Paredes, I., Álvarez-Sierra, M.Á., van den Hoek Ostende, L.W., Hordijk, K., Oliver, A. \& Peláez-Campomanes, P. 2011. Biostratigraphy or biochronology? Lessons from the Early and Middle Miocene small mammal events in Europe. Geobios, 44, 309-321; doi: 10.1016/j.geobios.2010.11.004.

van der Meulen, A.J., Paredes, I.G., Sierra, M.Á., van den Hoek Ostende, L.W. \& Hordijk, K. 2012. Updated Aragonian biostratigraphy: Small mammal distribution and its implications for the Miocene European Chronology. Geologica Acta, 10, 159-179; doi: 10.1344/105.000001710.

Zelditch, M.L., Swiderski, D.L., Sheets, H.D. \& Fink, W.L. 2004. Geometric Morphometrics for Biologists. A Primer. Elsevier Academic Press, USA.

Zelditch, M.L., Wood, A.R., Bonett, R.M. \& Swiderski, D.L. 2008. Modularity of the rodent mandible: integrating bones, muscles, and teeth. Evolution \& Development, 10, 756-768; doi: 10.1111/j.1525-142X.2008.00290.x.

Ziegler, R. 1983 Odontologische und osteologische Untersuchungen an Galerix exilis (Blainville) (Mammalia, Erinaceidae) aus den miozänen Ablagerungen von Steinberg und Goldberg im Nördlinger Ries (Süddeutschland). Ph.D. Thesis, Ludwig-Maximillians-University, Munich. 
